\title{
The Evolution of Rock Festivals in Greece
}

\author{
Michael Tsangaris, PhD \\ University of Piraeus, Greece
}

Doi:10.19044/esj.2019.v15n23p115 URL:http://dx.doi.org/10.19044/esj.2019.v15n23p115

\begin{abstract}
There is a steady growth of music festivals that has continuously occurred within the last thirty years, and this has changed the structure of the international cultural market. Nowadays, selling recorded products does not make large profits and music festivals became the vital supporters of the music industry. This paper focuses on presenting how the growth of rock festivals introduced to Greek society a new kind of entertainment quite different from the traditional festivities of the region and how this practice supports tourism. Indeed, some great festivals are created with the international market in mind and are based on specialized tourism management practices. This study, after considering some aspects concerning the interaction between global and local music culture, provides a brief historical framework of the rock festivals. It constitutes basically a general review presenting the evolution of this imported type of entertainment in Greece, and it reveals possible commonalities between the traditional and the new forms of festivities. Although there are significant differences between Panygiri which is the old traditional Greek festivity and the rock festival, it seems that some fundamental elements in those social phenomena such as attracting tourism and uniting people always remain the same.
\end{abstract}

Keywords: Festivalisation, rock festivals, Greece, music industry, festival tourism

\section{Introduction}

Since the second half of the twentieth century, the term "cultural imperialism" raised an argument that intensively concerned both cultural and media studies (White, 2001). Boyd-Barrett (1998) considered media imperialism as the unbalanced set of relationships between countries in the sphere of media leading to a state of dependency or dominance. Furthermore, it was suspected that this condition may bring distorting effects to national identities (Straubhaar, 1991). According to Hesmondhalgh (2004), the term "cultural imperialism" implied that a new form of international control was developing since the age of direct political and economic domination by 
colonial powers was over. This new type of hegemony was based on indirect cultural control. Imported western cultural forms could overrun the traditional culture of less-developed countries. Thus, the global corporations dominated non-western economies by encouraging a desire on the part of their populations for western products and lifestyles.

Over the years, music was played by the performer just for his personal enjoyment or in front of an audience. The argument concerning live music, as an alternative, theoretically came up after the invention of sound recording. Technology that grew exponentially during the twentieth century in western societies changed the way people perceive and understand the concept of music worldwide. Thus, what sets the definitions and the conventions for music products, performers, and consumers is the western music art-word ${ }^{2}$ (Becker, 1984), technology, and the international commercial system.

Up to date, several analyses have been made concerning the relationship between music industry and cultural imperialism (Frith, 1991; Garofalo, 1993; Hesmondhalgh, 2004; Kim \& Shin, 2010). For Wallis and Malm (1984), the concept of cultural imperialism has both an economic and a cultural dimension. Since the nineteen twenties and until the end of the twentieth century, the dominant power of the music industry was the major recording companies. Most of the income received by the music industry was derived from recorded music market. Thus, this means direct sales in the record shops, radio, and television fees to broadcast recorded music, etc. For many years, five significant major companies ruled the international record industry: CBS, WEA, RCA-Ariola, PolyGram, and EMI ${ }^{3}$ (Laing, 1986).

Rock and roll emerged in United States in the fifties, mixing rural and urban guitar styles of rhythm and blues, country and jazz. It developed progressively into a great range of different rock genres, offering many promises to the music industry for profits. However, at the same time, rock music served as a catalyst promoting alternative libertarian lifestyles and modes of social action towards particular goals that were usually against the establishment.

The market dominance and the innovative musical culture of the Anglo-American societies in the late twentieth century stressed people all over the world to get involved and decide either to accept pop-rock music and occasionally mix it with the indigenous elements or to take a distance from it.

\footnotetext{
${ }^{2}$ As Becker asserted, the term "art-world" leads to a tautology if we consider that it is a network of individuals and groups organized into collective activities based on their common knowledge of the conventional ways of doing and perceiving "Art". This is according to conventions that the same network defines (Becker, 1984).

${ }^{3}$ By 2000, the landscape of the recording industry had changed as most of the recording labels had been acquired by five majors: EMI, BMG, Sony, Universal Music, and Warner Music. However, BMG was later acquired by Sony (Koster, 2008).
} 
Although the arrival of rock and roll in many countries was seen by the formation of the local music art-words as a model of cultural invasion, the young people always embraced it enthusiastically (Bozinis, 2008).

All music genres coming from western countries usually grew over time to dominate the international music industry (rock, disco, rap, hip-hop, etc). However, local music genres from the South found it difficult to gain exposure in the international market. On the other hand, if they succeeded sometimes, it was under the control of the dominant music industry. One way or the other, some local musical genres have managed to enter the international circuit, such as Latin, Caribbean or Southern African, etc. (Throsby, 2002).

Nowadays, considerations about cultural interactions within the international framework have changed. The term "cultural imperialism" fainted from the public discourses and globalisation is now the new word used by scholars to study the relationships between different cultures (Hesmondhalgh, 2004). Nevertheless, the global economic system of the major recording companies has given its place to the new western commercial network of music festivals. This shift from the recording model to the live sector by the music industry that took place unexpectedly all around the world proves once more the dominance of western practice concerning the developments of cultural production. Furthermore, the expansion of festival culture globally and the increasing professionalism in this realm via education and vocational specialization indicates a positive recognition that festivals make an important contribution for the entertainment and tourist industry (Robinson \& Long, 2004; Olaniyan, 2014).

\section{Methodology}

This qualitative study aims to present the developments concerning new forms of cultural production that are imported by the western countries in South Europe and more precisely in Greece as innovative patterns of entertainment industry and cultural event tourism.

Initially, by investigating the existing academic research, the main themes of the inquiry were introduced. This includes the traditional Greek Panegyri feasts, the rock festivals, and the concept of society's 'festivalisation' followed by a brief historical preview of international and Greek rock festivals.

In order to examine the course of rock-pop festivals in Greece, this study drew secondary data from the academic literature, the music press, festivals posters, programs or flyers, as well as online festival sites and databases. The duration for data collection lasted from January to October 2018 and covered festivals from the period 1985-2018. In total, thirty-five festivals were examined including River Party (est. 1985) at Kastoria, Chania Rock Festival (est. 2002), Let's Rock festival (est. 2002) at Athens, Coca Cola 
Echoes of You Rock Festival (2004) at Thessaloniki, Schoolwave Festival (est. 2005) at Athens, EJEKT Festival (est. 2005) at Faliro, Fly Beeyond Festival (est. 2007) at Athens, Arm Your Desires Festival at Tirnavos (est. 2008), Street Festival of Kalamata (est. 2009), Reggae Vibes Music Festival (est. 2009) at Almyros Beach of Agios Nikolaos in Crete, Ziria Music Festival (est. 2009) at Trikala of Corinth, Street Mode Festival (est. 2010) at Thessaloniki, Festival Vrisis Tirnavou (est. 2011), Los Almiros Festival (est. 2012) at Almiros of Magnesia, Saristra Festival (est. 2012) at Vlahata Samis in Kefalonia, Fenefest (est. 2016) at Lake Doxa in Corinth, Fuzztastic Planet Festival (est. 2013) at Drama, Rock Mountain Festival (est. 2013) at Agia Marina in Ioannina, Lakos Music Festival (2014) at Litohoro, IN-Fest (2014) at Kilkis, Prairie \& Rust (2015) at Athens, Paxos Reggae Festival (2015) at Paxous, Over The Wall - Crete Rock Festival (2016) at Heraklion of Crete, Release Athens Festival (2016), Festival Agias (2017) at Larissa, Matala beach festival (2017) in Crete, Under The Sun Rock Festival (2018) at Shinos of Corinth, Boom Reggae Festival (2018) in Skýros, Evvoia, Athens Retro Festival (est. 2016). Furthermore, some political parties' festivals were taken into consideration including alternative Antifa, Antiracist, and Libertarian Festivals.

Research was conducted by a content analysis of the gathered texts focusing on remarks concerning the organization, the genre, the purpose, and the target audience of each festival.

The overriding queries for the investigation of the data purported to answer the following: Firstly, to determine if there were any similarities between the traditional Panegyri feasts and each of this rock festivals; secondly, to establish if there was any potentiality for the Greek rock festivals' categorization into explicit subgenres; and finally, to verify if there was any relation between the Greek rock festivals and tourism.

\section{Festivals}

According to Falassi (1987, p.2)

'the definition that can be inferred from the works of scholars who have dealt with festival while studying social and ritual events from the viewpoint of various disciplines such as comparative religion, anthropology, social psychology, folklore, and sociology indicates that festival commonly means periodically recurrent, social occasion through which a multiplicity of forms and a series of coordinated events participate directly or indirectly and to various degrees all members of a whole community are united by ethnic, linguistic, religious, historical bonds and sharing a worldview. Both the social function and the symbolic meaning of the festival are 
closely related to a series of overt values that the community recognizes as essential to its ideology and worldview, to its social identity, its historical continuity, and to its physical survival, which is ultimately what festival celebrates'.

The traditional festival in Greece is called Panegyri, and it is mostly associated to the local community's patron saint. Since the Byzantine times, pilgrims and regional populations were gathering around churches, chapels, and village squares, on the occasions of religious feasts, accompanied by a range of secular activities. Such happenings included open-air markets and local bands playing music accompanied by folk songs, traditional dances, food and drinks (Vozikas, 2007).

During the second half of the twentieth century, according to Van Elderen (1997), the increasing 'festivalisation' of society reflected the symbolic transformation of the public space into a certain form of cultural consumption. Many reasons can be attributed to this rapid growth of the festival culture across continents. This includes socioeconomic factors concerning supply (economic development, event tourism, etc.) and demand (building community bonds, need for new lifestyle patterns, recreation, etc.) of the local regions. The technological innovations in communications and transportations, the rapid expansion of tourism, as well as the upgrading of people's education played a significant role in this direction (Prentice \& Andersen, 2005). Another reason for the constant increasing of the festival culture comes from the fact that many societies aim to promote their culture globally for political and economic reasons. Thus, festival tourism can be a decisive channel for the promotion of new products, ideologies, values, arts, lifestyles, etc.

According to Négrier (2014, p.1), 'festivalisation is the process by which a cultural activity, previously presented in a regular, on-going pattern or season, is reconfigured to form a new event'. He argues that festivalisation also describes the procedure by which cultural institutions, such as movie houses, theatres, arts centers or galleries focus part of their programs around themes or events for a certain period. Therefore, festivalisation is the result of festivals explosion but also the outcome of regular cultural practices, 'eventalisation', and commercialization. The current situation in Europe shows an interesting tension between those developments. In this sense, Clark and Aspden (2004) noted that contemporary festivals can be correlated to super-markets where the public is invited to buy culture.

Nowadays, the meaning of the term "festival" covers a wide range of periodically repeated religious or secular processes, maintaining events such as carnival feasts, religious celebrations, music performances, serial presentations of films, art exhibitions, series of theater plays, brand-name promotions, traditional products expositions, science and technology 
demonstrations, food and beverage revelries, seasonal and harvest celebrations, etc.

Additionally, festivals since antiquity reflect the culture of the society respectively.

Thus, festivals in the present day can include a wide variety of themes promoting products and entertainment not directly related to the traditions of the local community. In effect, festivals are becoming globally dominant features of the culture industry with a growing economic importance on the development of tourism (Andersson \& Getz, 2008; Anderton, 2011; Tohmo, 2005). In the long run, imported recreative patterns that festivals promote can get established and may become very important also for the people of the hosting community and finally a part of their culture. Consequently, event management that introduces innovative products and services for tourists and the local consumers can inevitably influence local cultures.

\section{Rock Festivals}

A rock concert is a public live musical stage performance by one or more musicians of rock music in front of an audience in an open or closed space (stadium, arena, theatre, etc.). It was stated that the first live rock concert ever was the Moondog Coronation Ball in Cleveland, Ohio in 1952, which was promoted by Alan Freed who is often referred to as the father of rock and roll (Perl, 2014). Nowadays, the word "rock festival" usually denotes periodically repeated large-scale concerts carried out by varied musicians that embrace diverse genres of rock music ${ }^{4}$. Sometimes, various activities also take place in the festival areas including theatre, cinema, poetry presentations, literary discussions, art exhibitions, tattoo-making, haircutting, accommodation, as well as clothes, shoes, records, badges, books, and poster markets. In this way, the concept of subcultural unity and celebration is enriched (Bowen \& Daniels, 2005).

As Seiler (2000) noted, at the beginning of the twentieth century, recorded music prevailed over live performances. It became the essential profitable medium for artistic expression and the basic product of the music industry. However, concerts and festivals remained as sites of confirmation where the bands were appraised by the audience as authentic, genuine, and superior, proving that they are worth buying their records. Besides, live performances affirmed people's commitment to music genres and simultaneously led to the sharing of the same social and political beliefs.

\footnotetext{
${ }^{4}$ However, many great festivals were unique events such as Woodstock Festival or Rock in Athens, etc. Furthermore, many rock festivals are defined by their genre like the punk rock Rebellion festival at Blackpool or the Bedlam psychobilly festival at Northampton. In this sense, periodicity and genre variety are not decisive characteristics of rock festivals.
} 
The increasing advance of music festival culture initiated an extensive academic discourse regarding the commercialization and the carnivalesque perspectives of the rock festivals. The outdoor music festivals sprung from the United States and Britain in the mid-fifties (Newport Jazz Festival, Beaulieu). This type of event quickly expanded to become a significant part of the youth culture (McKay, 2000). During the sixties and the seventies, the culture of new social movements challenged the lines between high and low culture and gradually brought about changes in the conception of festivals (Quinn, 2005). The further diffusion of music festivals during the late sixties (KFRC in 1967, Monterey in 1967, Woodstock in 1969, etc.) for many scholars is attributed to the experimentation with alternative lifestyles and the hippie youth culture (McKay, 2000; Sandford \& Reid, 1974).

The Woodstock festival that took place in 1969 in Catskill Mountains near New York is regarded as a pivotal moment in rock festivals history. This event was one of the largest music gatherings of the era and it was granted by the promoters as 'an Aquarian Exposition: 3 Days of Peace and Music'. Bands and musicians such as the Jefferson Airplane, Janis Joplin, Jimmy Hendrix, the Grateful Dead, Country Joe and the Fish, Crosby, Stills, Nash \& Young, etc. played in front of thousands of people ${ }^{5}$. Initially, it was designed as a profit-making project by four entertainment businessmen (Lang, Roberts, Rosenman, and Kornfeld) based on a business plan, but it finally became a free concert. Following the same trend, a great number of festivals were launched in Western Europe (Glastonbury, Isle of Wight, Pinkpop, etc.). Many of these festivals were initially influenced by hippie ethics and the free festival movement, but they progressively grew and became international commercial events.

Framing festival culture through commercialization makes possible claims that Woodstock and the succeeding rock festivals that have flourished in the kaleidoscopic ambience of the new social movements also induced potentialities for commodification of the rebellion (Seiler, 2000). A historical review of the rock festivals depicts a problematic hybridization of commercial and idealistic considerations that is analogue to the sacred-profane dichotomy that examined Durkheim (1995).

While most of those festivals were commercial events ${ }^{6}$, they were also related to political issues and usually raised impressive protests. Within this period, most of the rock scenes were uncertain about the establishment and proposed alternative ways of action. Rock songs and folk ballads including

\footnotetext{
${ }^{5}$ According to Dixler (2010), an unexpected number of 400,000 people gathered in Max Yasgur's farm on Friday, August 15 of 1969, for a weekend of rock music.

${ }^{6}$ Some festivals came under intense criticism from the more radical elements of the counterculture movement like the Isle of Wight Festival (Worthington, 2004; Hinton, 1995; Clarke, 1982).
} 
pro-civil rights and anti-war lyrics politically influenced the western youth culture and inspired people to actively get involved in social movements. Listening to rock music and going to rock festivals became a conscious political expression and a way of supporting rebellion, freedom, peace, and social equality.

In the early seventies, commercial promoters began to lose faith in large-scale music festivals. However, the arena rock scene with dramatic live performances and special lighting effects attracted large audiences in stadiums worldwide. All those giant unique shows increased ticket prices and constructed international rock stars (Brennan, 2010; Laing, 2004). After a while, by the late seventies and the early eighties, the punk scene emerged through live performances usually in small clubs and pubs. However, a great part of it finally got integrated into the commercial networks of the music industry (Worley, 2017). In any case, outdoor rock festivals continued throughout the seventies and the eighties successfully (Reading, Glastonbury, Hurricane Festival, Midtfyns Festival, etc.).

During the nineties and the following decades, while the commercial enterprises globally experimented with new live music forms of promotion (Heineken Music Festival, V festival, Vans Warped Tour, iTunes Festival/Apple Music Festival, etc.), the festival culture started to change face. In addition, the rise of the alternative rock scene and the expansion of the multi-stage festival form with a wide range of various bands playing concurrently in different stages allowed a large heterogeneous audience to attend festivals, bringing various neo-tribes ${ }^{7}$ and brand communities ${ }^{8}$ together (Cummings, 2007; Fitzgerald, 2013). Festival stages were usually devoted to specific genres of music and sometimes those stages and their audience became so large to be developed into festivals themselves as with the Glade Festival that came up from Glastonbury (Music tank, 2008).

After the millennium, most of the music festivals became significant commodities since recorded music was disrupted by the new digital and network technologies. Nowadays, recorded products' sales do not make large profits. However, big festivals can bring worthwhile revenues, and this plays an important role in keeping the music industry active (Gordon, 2011; Marshall, 2012; Mulligan, 2015).

\footnotetext{
${ }^{7}$ Maffesoli (1996) describes tribes as informal social networks or collective associations that are not bounded by traditional modern structural organisations as they refer more to a certain ambience or a state of mind that is expressed through lifestyles that favour appearance and form (Cummings, 2007, Bennett, 1999).

${ }^{8}$ Brand community, according to Kalman (2005), is a term that describes like-minded consumers who identify with a particular brand and share significant traits, consciousness, rituals, traditions, and a sense of moral responsibility.
} 
Organizers exploit people's sense of authenticity and the social distinction of "being there" for increasing ticket prices and boost merchandising ${ }^{9}$ (Scher, 1997; Seiler, 2000). Music festivals and concerts turn out to be successful in attracting more and more event sponsors. This is because, nowadays, music festivals and concerts are extremely popular and attract thousands of people. Therefore, advertisers consider them as places where multiple products can be promoted easily (Oakes, 2003).

Today, most of the big music festivals can be considered as commercial events that promote their sponsors and are basically grounded in management ethics (Sziget, Pinkpop, Lowlands, Rock Im Park, etc.). Live Nation, the global leader company in entertainment that organizes more than ninety festivals in forty countries (Live Nation Entertainment, 2018), sold more than fifty-two million tickets globally in 2017, AEG presents more than fourteen million, OCESA-CIE more than four million, and so on (Statista, 2018).

On the other hand, political, unlicensed, and free music festivals are still apparent since the seventies and onwards (Phun City, Glastonbury Fayre, Trentishoe Festival, Deeply Vale Festivals, Rock Against Racism, Zig-Zag anarcho-festival, Dragon Festival, etc). Many scholars consider those festivals as a form of modern carnivalesque (Anderton, 2011; Blake, 1997; Hetherington, 2001; Hewison, 1986; McKay, 2000).

Political festivals strongly support a political reason, while the unlicensed festivals are unauthorized and illegal. Finally, the free festivals are free in the sense that there is no entrance ticket, the musicians play for free, and there is minimal administration and authority. Ubi Dwyer, the originator of the Windsor Great Park free festivals in London, emphasized that "free festivals are practical demonstrations of what society could be like all the time" (McKay, 1996). Free festivals require the active participation of everyone and promote a communal way of life as an alternative to the increasing consumer culture (Griffin et al., 2016; Worthington, 2004). The culture of free festivals was developed in parallel with the commercialized version during the seventies and continued throughout the eighties influenced by feminism, environmentalism, the emergence of punk, and other protest groups. Nevertheless, many festivals rooted in the political countercultural heritage progressively grew, became recuperated by the economic establishment, and was converted to international commercial events.

\footnotetext{
${ }^{9}$ According to Seiler (2000, p.215), although merchandising exists since the early days of rock and roll, today it "represents another technique of exploiting consumer by offering an item such as a T-shirt, poster, button, or program-design to commemorate the event and testify the fans attendance and devotion".
} 


\section{Rock Festivals in Greece}

It is said that the first rock concert in Greece took place in 1956 in the club Aegli Zappiou of Athens (Bozinis, 2008). It was the same year that the film Blackboard Jungle (Brooks, 1955) was on the Greek cinemas. The United States Sixth Fleet jazz band, that was playing there that morning, was asked by the audience to play rock and roll music (Symvoulidis, 2012). When the band played "...a wind of crazy party was spread over the people. The loudspeakers were vibrating this fast, breathless, anxious, and imposing beat of the new rhythm. People were shouting, clapping their hands, and tapping their legs trying to keep up with the beat..." (Ethnos, 1956).

Until the end of the fifties, only a couple of famous groups (Platters, Chacachas) played in the Greek clubs. Although the state radio stations avoided playing rock music, the American Base's radio station in Athens (A.F.R.S), as well as Radio Luxembourg and Radio Monte Carlo regularly transmitted the new sound. At the same period, there was a festival of fashion touring all over Greece, which was organised by an Athenian businessman that carried through live rock and roll music by Greek musicians for the young girls to practice dancing (Bozinis, 2008).

In the sixties, rock and pop concerts performed by Greek bands such as the Forminx, the Olympians, the Charms, the Idols, M.G.S, etc. were very common in cinema theatres, small indoor arenas, bars, and clubs. Usually, the Greek bands apart from their compositions were playing covers of famous pop and rock hits. This was sometimes translated in the Greek language. However, apart the convivial and carnivalesque gathering of the hippy community in the caves of Matala in Crete, that did not carry out any organized concerts but supported the sixties countercultural heritage, no great international event such as a big concert or festival took place until the late sixties. Occasionally, Dutch or German bands were presented in the clubs of Athens imitating the famous British and American bands ${ }^{10}$. Eventually, on the seventeenth of April in 1967, the first great concert took place in Greece by the Rolling Stones and many other Greek bands including the Idols, Dakis, M.G.S., Loubogg, Tassos Papastamatis, Guidone, and We Five. Unfortunately, when Mick Jagger started to throw red carnations to the audience, the police considered this behaviour as an act of rebellion and stopped the concert. Great riots grew rapidly inside and around the stadium causing many damages and this fact became the occasion for the authorities to keep international rock concerts and festivals out of Greece for many years after. Nevertheless, four days later, the

\footnotetext{
${ }^{10}$ At this point, it is worthwhile to mention the initiation of the Thessaloniki Song Festival in 1959 that was supported initially by the Greek Music Association and then by the Hellenic Broadcasting Corporation, which was a Greek song contest. Although rock elements may have been included in some of the performances sometimes, the entire project is far from the subject that we investigate.
} 
military junta broke out. Therefore, apart from all other civil liberties suppressions, it banned the outdoor gatherings for a long time and restricted the rock culture.

After then, within the next years, some attempts were made from the authoritarian regime to formulate cultural policies considering music such as the Song Olympiads (1968-1973). Although these events sometimes included songs with rock elements, they were actually state propaganda and cannot be considered at all as rock festivals (Trousas, 2010). In any way, even at this suppressed political environment, the Greek rock groups continued to play in clubs such as Rodeo, Kyttaro, Attica or some cinema theatres and a few concerts with foreign artists sporadically took place including Rocky Roberts, Marmelade, Cat Stevens, etc. (Bozinis, 2008). It is worthwhile to mention that in November of 1970 at the Woodstock (Wadleigh, 1970) film premiere in Athens, a crowd of youngsters outside the theatre caused confusion and public disorder and there were conflicts again with the police. Thus, rock festival culture in Greece was suppressed for a long time by the authoritarian regime.

During the second half of the seventies, small scale pop-rock festivals became common practice for the Greek rock bands. However, most of the times, the term "pop festival" was used in general to denote concert.

Some years later in the early eighties, concerts of foreign bands progressively begun to take place starting with Lene Lovich, the Police, Ian Gillan band, Ray Charles, Fisher Z, Tom Robinson band, Rory Gallagher, Dr Feelgood, Steppenwolf, Mike Oldfield, Eloy, City and others. In 1982, the first attempt was made from the music industry for the development of rock festivals with a small-scale three-day festival in the city of Athens, featuring the Fall, New Order, and the Birthday Party.

Eventually, the first large scale rock festival in Greece took place in the summer of nineteen eighty-five. Many famous rock (and pop) bands participated in the festival such as the Clash, Culture Club, the Cure, Depeche Mode, the Stranglers, Nina Hagen, Talk-Talk, and Téléphone. It was organized by the state (Greek Ministry of Culture) and the French private travel agency, Nouvelles Frontières. The event was called 'Rock in Athens'. It took place in the Panathenaic Stadium (Kallimarmaro) of Athens and it was a part of the celebrations for Athens being the first title-holder of the European City of Culture (European Capital of Culture). However, the coexistence of different music genres, subcultures, and socio-political attitudes that the invited bands represented was evident in the festival (Lagos, 2014).

The practice of big festivals with multiple foreign pop-rock groups gradually integrated into the local music market even without the state funding support.

Meantime, during this period in Athens, there is a boost of rock concerts, mostly small-scale, performed by Greek youth bands usually in 
schools, small clubs (Skylamb, Sofita, Pigasos, etc.), cinema theatres, and squats (Villa Amalias).

In 1987, the Rodon Club was opened and became one of the most important venues of rock culture in Athens where bands such as Ramones, the Cramps, Pixies, the Gun Club, Nick Cave, New Model Army, Sonic Youth, the Damned, Siouxsie and the Banshees, Died Pretty and many others played until it closed down in the year 2005. At the same time, the An Club appeared and hosted many international artists such as the UK subs, Nikki Sudden, Lydia Lunch, the Fuzztones, the Vibrators, the Fleshtones, etc.

In the summer of 1988, another great concert took place in Panathenaic Stadium of Athens. It was called a Marathon Against AIDS, and it followed the altruistic spirit of Live Aid concert (1985) that took place in Wembley Stadium of London against the ongoing Ethiopian famine. Famous musicians performed in this concert, such as Bonnie Tyler, Jerry Lee Lewis, Joan Jett, Run DMC, and Black Uhuru.

In the late eighties, rock culture was already diffused significantly among the Greek youth. This was due to many factors, such as the liberalization of the airwaves, the record companies' new marketing strategies, the rise of consumerism, satellite systems, the concerts industry expansion, etc. At the same time, several alternative rock festivals began to appear (do-ityourself festival at Villa Amalias or Pedion tou Areos, etc.).

At this point, it is worthwhile to mention that although the political parties' youth festivals initially avoided rock music in a way, but by late eighties they progressively started to include some rock elements in their programs.

One of the biggest rock festivals in Greece known as the Rockwave festival was established in 1996 which stabilized the commercial rock festival culture in Greece. It usually lasts from three to five days and takes place every summer in Terra Vibe, an open-air venue near the city of Athens. Over three hundred international and Greek artists have played in the scenes of this festival including the Sisters of Mercy, Blur, Garbage, Iggy Pop, Patti Smith, Oasis, Judas Priest, Placebo, Black Sabbath, Marilyn Manson, Guns N' Roses, Arctic Monkeys and many others.

Events following the egalitarian tradition which rose in the eighties are still going on with Antifa, Anti-Racist and many other kinds of libertarian music festivals. This includes rock concerts and constitutes some parts of a greater protest. All those festivals outline their antithesis against inequality and social discrimination. They are organized in order to bring together individuals who envision a world that has no place for any kind of social injustice (Second Antifa Festival of Lesvos, 2018).

A recent study that examined the rock-pop festivals that were currently taking place in Greece revealed that most of them were organized by 
entrepreneurs and business coalitions, cultural organizations, non-profit groups, political parties or municipal councils (Tsangaris \& Pazarzi, 2018).

\section{Discussion}

Although similarities and differences were evident between all those festivals, their decisive classification would be considered inconsistent since each event has its own character, form, and purpose. However, there are some broad groupings that attract the attention. Some of those festivals belong clearly to the commercial show business environment which attracts multiple sponsorships with the aim to achieve high profits. While some place high priority on community building, others are rooted in the political countercultural heritage of the sixties reducing as far as possible corporate sponsorships encouraging communal, altruistic, and environmental ideals. Furthermore, while others propose subcultural unity, others wish to promote local tourism and local nature. Some small festivals are only concerned with fun rather than commercial profit or regional development, etc.

The character of each festival delineates its purpose. In this respect, the goals that organizers presented considering their events include: hosting international stars of the rock scene and well-established bands, supporting rock music, offering fun and entertainment to the Greek audience, reinforcing community and subcultural bonds, promoting local bands and musicians, collaborating musical forces for the cultural upgrading of the region, matching magical locations and music enjoyment, offering people different modes of entertainment, protesting social discriminations and inequalities, supporting political views, developing free places of expression, etc.

The concert industry is one form of entertainment that remains untouched by the recent economic recession (Perl, 2014). In times of crisis, music festivals can be considered as tools for the economic development of a region. The topic of music tourism is progressively becoming very popular in leisure studies (Lashua et al., 2014). Accordingly, music festivals attain an increasing importance providing a competitive advance to tourist destinations that host them (Gibson \& Connell, 2005). They are crucial as they raise domestic and international tourism enhancing the images of locations. Many magnificent but uncharted areas in Greece are becoming known by rock festivals.

The large-scale rock festivals that take place in Greece are clearly projects based on business models, which are imported by the growing western entertainment industry. This proves that the Greek cultural practices receive significant influences from the models of cultural production employed by the western countries and may recall theories of cultural imperialism. Smaller activist rock festivals that usually struggle against social inequalities and injustices evidently follow the late sixties countercultural happenings that 
unfortunately never occurred in Greece. Although rather late, they still reflect evolved protest forms that are also imported from the western societies.

This investigation revealed that even though rock festivals follow imported cultural models, they still share some common values with the traditional Greek Panegyri. They are all rituals repeating sociocultural behaviors. They constitute a chain of actions, movements, and practices following standard protocols. They are practices that organize the social behavior of the community and revitalize it by maintaining social bonds.

Most of those festivities are always closely related to commerce, travelling, and tourism which attract people from distant regions. Visitors from faraway places are engaged to the events connected by their special interests, preferences, dedications, and symbols that shape their experience. Tourist motivation is a complex concept and there is no simple explanation to this attraction. Religion, spirituality, and rock music can equally relate people coming from distant areas and motivate them to travel and take part in festivals. Traditional Panegyri and contemporary rock festivals provide places for meaningful connectivity and spectacle for long distance visitors. Furthermore, due to the recently advanced communication and transportation technologies, festivals gained an enormous global appeal.

\section{Conclusion}

According to Falassi (1987, p.7), "festival has retained its primary importance in all cultures. This is because the human social animal does not still have a more significant way to feel in tune with his world than to partake in the special reality of the Festival and celebrate life in its time and out of time".

It is often difficult to disentangle economic from cultural considerations when analyzing the development of the festival culture.

Some festivals constitute cultural expressions that are related to the tradition of a place. While others follow the global music market, others promote ideological orientations. However, some festivals do not follow any of those roots.

The Greek Panegyri, the old village feast that originally has religious purposes but is often associated with the world of commerce, enhances the coherence of the community and expresses the collective nature of ideas and senses.

The evolution of rock festivals in Greece followed a very long course. This is mostly due to the political situation in the country during the late sixties when this form of entertainment started to grow larger.

Rock festivals may bring coherence to neo-tribes and brand communities to enhance their group identities which differ in various ways in terms of their functions and their social meaning from the traditional Panegyri. 
They may also come with a variety of types such as commercial, communal, political, protesting, etc.

The mainstream large-scale rock festivals were introduced clearly for commercial reasons to adapt the consumeristic way of life of the western countries. Those festivals following the logic of the global market can be considered as part of a process by which certain western cultural forms that are associated with entertainment become predominant everywhere.

Furthermore, all other types of alternative festivals that usually constitute forms of political demonstration in the framework of global justice movement against social discriminations and inequalities were also imported to Greece.

One way or the other, festivals attract external audiences and can be considered as significant forms for leisure and tourism. Both traditional Panegyri and rock festivals can be viewed and connected by their commitment to unite people and to promote cultural tourism.

Consequently, in order to attract tourists, some locations turn to cultural events such as rock festivals and sometimes even attempt to transform Panigiri, the old village feast, 'into a modern kind of entertainment which is built in today's conditions (Sarista Festival, 2018).

\section{References:}

1. Andersson, T. D. \& Getz, D. (2008). Stakeholder management strategies of festivals. Journal of Convention and Event Tourism, 9 (3), 199-220.

2. Anderton, C. (2011). Music festival sponsorship: Between commerce and carnival, arts marketing: An International Journal, 1 (2), 145-158.

3. Bassett, K. (1993). Urban cultural strategies and urban regeneration: a case study and critique. Environment and Planning A, 25(12), 17731788.

4. Becker, H. (1984). Art worlds. Berkeley: University of California Press.

5. Bennett, A. (1999). Subcultures or neo-tribes? Rethinking the relationship between youth, style and musical taste. Sociology, 33(3), 599-617.

6. Blake, A. (1997). The land without music: Music, culture and society in Twentieth-Century Britain. Manchester: Manchester University Press.

7. Bozinis, N. (2008). Rock globality and Greek locality. Athens: Nefeli.

8. Boyd-Barrett, O. (1998). The globalization of news, London: Sage.

9. Bowen, H. \& Daniels, M. (2005). Does the music matter? Motivations for Attending A Music Festival. Event Management, 9, 155-164. 
10. Brennan, M. (2010). Constructing a rough account of British concert promotion history. Journal of the International Association for the Study of Popular Music, 1(1), 4-13.

11. Brooks, R. \& Berman, P.S. (1955). Blackboard Jungle. [Motion Picture] United States. Metro-Goldwyn-Mayer.

12. Clark, A. \& Aspden, P. (2004). Highbrow, low blows. Financial Times Magazine, 19, 34-37.

13. Clarke, M. (1982). The Politics of Pop Festivals. London: Junction Books

14. Cummings, J. (2007). Selling the indie scene. Music festivals, neotribes and brand communities. In L. Cheshire, A. Broom (Eds.), Refereed Proceedings of the Joint Australian Sociological Association (TASA) and the Sociological Association of Aotearoa New Zealand (SAANZ) Conference.

15. Dixler, E. (2010). Back to the Garden: The Story of Woodstock and How It Changed a Generation. New York: Touchstone.

16. Durkheim, E. (1995). The elementary forms of Religious Life. New York: The Free Press.

17. Ethnos (22 October 1956). The United States Sixth Fleet in action at the center of Athens. 7.

18. Falassi, A. (1987). Festival: Definition and morphology. In A. Falassi (edt), Time out of Time: Essays on the Festival. Albuquerque: University of New Mexico Press.

19. Fitzgerald, D.G. (2013). The Un'Gathering of the Tribes: performing, writing, and remaking masculine identity at 1990s alternative rock festivals (Doctoral dissertation).

20. Frith, S. (1991). Anglo-America and its discontents. Cultural Studies 5(3). 263-269.

21. Garofalo, R. (1993). Whose world, what beat: The transnational music industry, identity, and cultural imperialism. The world of music, 35(2), 16-32.

22. Gibson, C. \& Connell, J. (2005). Music and Tourism: On the Road Again. Clevedon: Channel View Publications.

23. Gordon, S. (2011). The Future of the Music Business. Milwaukee: Hal Leonard Books.

24. Griffin, C., Bengry-Howell, A., Riley, S., Morey, Y., \& Szmigin, I. (2016). We achieve the impossible: Discourses of freedom and escape at music festivals and free parties. Journal of Consumer Culture, 18(4), 477-496.

25. Hesmondhalgh, D. (2004). Globalisation and cultural imperialism: a case study of the music industry. In R. Kiely, P. Marfleet (Eds.), Globalisation and the Third World (pp. 169-190). London: Routledge. 
26. Hetherington, K. (2001). New Age Travellers: Vanloads of Uproarious Humanity, London: Cassell.

27. Hewison, R. (1986). Too Much. Art and Society in the Sixties. London: Methuen.

28. Hinton, B. (1995). Message to Love: The Isle of Wight Festivals, 196870. Chessington: Castle Communications.

29. Kalman, D. M. (2009). Brand communities, marketing, and media. Terrella Media Inc. Retrieved at. https:/www.terrella.com/wpcontent/uploads/2009/01/kalman-brand-community-marketing1.pdf accessed 14.09.2018.

30. Kim, P. H. \& Shin, H. (2010). The birth of rok: Cultural imperialism, nationalism, and the glocalization of rock music in South Korea, 19641975. positions: east asia cultures critique, 18(1), 199-230.

31. Klaic, D. (2006). Festival Lexicon. Performance Research, 4(11), 5455.

32. Koster, A. (2008). The emerging music business model: back to the future?. Journal of Business Case Studies, 4(10), 17-22.

33. Lagos, E. (2014). Rock in Athens, youth and mass culture, In V. Vamvakas and P. Panagiotopoulos (Eds.), Greece in the eighties. Athens: Epikedro.

34. Laing, D. (2004). The three Woodstocks and the live music scene. In A. Bennett (Ed.), Remembering Woodstock, (pp. 1-17) Aldershot: Ashgate Publishing.

35. Laing, D. (1986). The music industry and the cultural imperialism thesis. Media, culture \& society, 8(3), 331-341.

36. Lashua, B., Spracklen, K., \& Long, P. (2014). Introduction to the special issue: Music and tourism. Tourist Studies 14(1), 3-9.

37. Live Nation Entertainment, Inc. http://www.livenationentertainment.com/ accessed 14.09.2018.

38. Maffesoli, M. (1996). The time of the tribes: The decline of individualism in mass society. London: Sage

39. Marshall, L. (2012). The 360 deal and the new music industry. European Journal of Cultural Studies, 1, 77-99.

40. McKay, G. (2000). Glastonbury: a Very English Fair. London: Victor Gollancz.

41. McKay, G. (1996). Senseless Acts of Beauty: Cultures of Resistance Since the Sixties. London: Verso Books.

42. Muir, E. (1997) Ritual in early modern Europe. Cambridge: Cambridge University Press.

43. Mulligan, M. (2015). Awakening: The Music Industry in the Digital Age. MIDiA Research. 
44. Music tank, Nick Ladd-Promoter and Co-founder, Glade Festival. Retrieved from http://www.musictank.co.uk/resources/speakerbiographies/nick-ladd-promoter-co-founder-glade-festival/ accessed 17.09.2018.

45. Négrier, E. (2014). Festivalisation: Patterns and Limits. Festival in Focus, Essays in tribute to dragan Klaic. HAL-01436610.

46. Oakes, S. (2003). Demographic and Sponsorship Considerations for Jazz and Classical Music Festivals. The Service Industries Journal, 23(3), $165-178$.

47. Olaniyan, M. E. (2014). An appraisal of Osun Osogbo as a festival theatre. European Scientific Journal, 10(11), 326-336.

48. Perl, S. (2014). The Economics of a Rock Concert. New York: Crabtree Publishing Company.

49. Prentice, R. \& Andersen, V. (2005). Festival as creative destination. Annals of Tourism Research, 30(1), 7-30.

50. Quinn, B. (2005). Arts festivals and the city. Urban Studies, 42(5/6), 927-943.

51. Robinson, M. \& Long, Ph. (Eds) (2004). Festivals and Tourism: Marketing, Management and Evaluation. Sunderland: Business Education Publishers Ltd.

52. Sandford, J. \& Reid, R. (1974). Tomorrow's People. London: Jerome.

53. Sarista Festival. Retrieved from https://saristrafestival.gr/festival-info accessed 14.09.2018.

54. Second Antifa Festival of Lesvos. (28-29.09.2018). Retrieved from http://voidnetwork.gr/2018/09/14/2nd-antifa-festival-lesbos/ accessed 14.09.2018.

55. Scher, J. (1997). Let's take it outside, shall we?. Brandweek, 38(8), 2225.

56. Seiler, C. (2000). Rock Culture and Consumer Capitalism In M. Gottdiener (Ed.) New forms of consumption: Consumers, culture, and commodification (203-226). Lanham: Rowman \& Littlefield.

57. Soundtracks: Music, Tourism and Travel International conference: 69 July 2012, Liverpool, United Kingdom, Retrieved from https://soundtracksconference.wordpress.com/. accessed 22.09.2018.

58. Statista, Leading music promoters worldwide in 2017 , by number of tickets sold (in millions) Retrieved from https://www.statista.com/statistics/304982/leading-music-promotersworldwide/ accessed 14.09.2018.

59. Straubhaar, J. D. (1991). Beyond media imperialism: Assymetrical interdependence and cultural proximity. Critical Studies in media communication, 8(1), 39-59. 
60. Symvoulidis, H. (2012). The Greek Sixties. In N. Sverkos (ed.), Half century of Greek rock. Athens: sonik-oxy.

61. Throsby, D. (2002). The music industry in the new millennium: Global and local perspectives. Global Alliance for Cultural Diversity Division of Arts and Cultural Enterprise. UNESCO, Paris.

62. Tohmo, T. (2005). Economic Impacts of Cultural Events on Local Economies: An Input-Output Analysis of the Kaustinen Folk Music Festival. Tourism Economics, 11.3, pp. 431-451.

63. Trousas, F. (2010). Vinylmine. Retrieved from https://diskoryxeion.blogspot.com/2010/10/1.html accessed 20.09.2018.

64. Tsangaris, M. \& Pazarzi, I. (2018). Changes in the cultural production of Southern Europe: the evolution of the rock festival culture in Greece Social Structures, Culture and Institutions in Southern European Societies. European Sociological Association/RN27 Catania, October 2018.

65. Van Elderen, P. L. (1997). Suddenly one summer: a sociological portrait of the Joensuu Festival. Joensuu: University Press, Joensuu.

66. Vozikas, G. (2007). The open-air markets of the capital's religious festivals. Lographia: a bulletin of the Hellenic Folklore Society. No.MA, p:195-214.

67. Wadleigh, M. \& Maurice, B. (1970). Woodstock [Motion Picture] United States. Warner Bros.

68. Wallis, R. \& Krister, M. (1984). Big Sounds from Small Peoples: The Music Industry in Small Countries. London: Constable.

69. White, L. A. (2001). Reconsidering cultural imperialism theory. Transnational Broadcasting Studies, 6, 1-17.

70. Worthington, A. (2004). Stonehenge: Celebration and Subversion. Loughborough: Alternative Albion.

71. Worley, M. (2017). No Future: Punk, Politics and British Youth Culture, 1976-1984. Cambridge: Cambridge University Press. 